\title{
Analyzing the Challenges to Using Technology in Physical Education
}

\author{
Gita Febria Friskawati \\ STKIP Pasundan \\ Cimahi, Indonesia \\ gita032@gmail.com
}

\author{
Vicki Ahmad Karisman \\ STKIP Pasundan \\ Cimahi, Indonesia
}

\author{
Mesa Rahmi Stephani \\ Faculty of Sport and Health Education \\ Universitas Pendidikan Indonesia \\ Bandung, Indonesia
}

\begin{abstract}
This survey research aims to explore the challenges of using technology in Physical Education. The data was taken through a survey using an open-ended questionnaire that has been distributed through Google forms which were distributed over two months and five days. The population is 49 Physical Education teachers in West Java. The population consisted of 13 Physical Education teachers from Cimahi, 9 from Bandung, 11 from Batujajar, 8 from Garut and 8 from Purwakarta. The total Sampling was used in this study. Data analyzed using the percentage of each indicator in the questionnaire. The results showed that the challenges obtained from teachers was $28 \%$, challenges from students was $24 \%$, challenges that came from the environment $32 \%$ and challenges from school support was only $16 \%$. These results can be used to overcome the problem of using technology in the Physical Education learning process at school.
\end{abstract}

\section{Keywords: challenges, using technology, Physical Education}

\section{INTRODUCTION}

Technological developments and applications involving computers and network technology have been developed rapidly in society. This development has penetrated in several aspects of community life; one of them is Physical Education. Several studies have explained the extraordinary benefits of the application of technology in learning can be felt for students to equip their skills in using technology in the future [1]. At the cognitive level, technology integration in the Physical Education learning process can also improve students' cognitive abilities and motivation [2]. In affective level, technological involvement in the Physical Education learning process is effective in maintaining student attention and interest in Physical Education learning and can increase student's motivation [3]. At the psychomotor level, the impact is still doubtful, it turns out to be able to increase the level of physical activity of students in the Physical Education learning process, [4] and able to improve students' motor abilities [5]. The results of this study prove that the integration of technology in Physical Education is very beneficial for students holistically.

The development and application of this technology has forced schools and Physical Education teachers to be willing to use it. Schools should provide facilities to support technology-based learning. Physical Education teachers must be able to create a learning atmosphere that can deliver students to achieve learning goals using technological media. It is a challenge for schools and Physical Education teachers to be able to feel the benefits. Some challenges arise to be able to integrate technology in the Physical Education learning process, the lack of understanding of schools about the importance of technology integration in Physical Education learning is one of the hardest challenges for the implementation of technology integration in Physical Education learning [6]. This understanding will have an impact on the creation of a learning environment to support the Physical Education learning process using technology, such as the provision of facilities and infrastructure to support its implementation.

Another challenge is that not all school members understand the importance of integrating technology into the learning process [7]. Also, Physical Education teachers who are not all literate about the use of technology are a challenge. Physical Education teachers should strive to integrate technology in the learning process and directing them to achieve optimal Physical Education learning goals for students, [8]. This technology will greatly help Physical Education teachers to receive information about teaching materials. The use of technology will also be a complement for teachers to be able to demonstrate the movement skills that will be learned during Physical Education through videos that are displayed on the screen. Both teachers and students will get more information and make it easier to transfer information about teaching materials in Physical Education learning [9].

However, when teachers use technology in the Physical Education learning process, sometimes students are not ready to accept it. The challenge for students lies in the level of understanding of students in using technology intelligently for learning education, [9]. There are still many students who not fully understand the use of technology in the learning process. The implementation of technology use in Physical Education learning will be achieved well if all aspects such as teachers, students, and school support for each other support each other [10].

The use of technology applied by Physical Education teachers in the learning process including video recorders about movement techniques in sports, films related to sports, the internet, and mobile applications such as to improve physical fitness can be downloaded on the AppStore [5]. However, the availability of infrastructure that supports learning such as the availability of internet nets, the 
The challenges issued by teachers were $28 \%$, the challenges obtained by students were $24 \%$, the challenges that came from the environment $32 \%$, and the challenges from school support were only $16 \%$. Based on this challenge indicator, the biggest challenges using technology in Physical Education learning are challenges that come from the environment with a presentation value of $32 \%$, followed by challenges coming from teachers as much as $28 \%$, students $24 \%$ and allocation of assistance from schools as much as $16 \%$.

In this study, environmental factors become the biggest challenge of using technology in Physical Education learning. The key to technology integration in the teaching and learning process of Physical Education is the availability of supporting facilities and infrastructure, such as the availability of the internet and other multimedia equipment [11]. Ease of access through the internet network, the availability of computer labs, projectors, digital cameras and multimedia such as audiovisuals that attract students also to increase student motivation when the learning process takes place [12]. This will foster positive attitudes of students in learning Physical Education. Although the benefits have been widely expressed, schools that are not yet technologically literate often do not provide technological tools that can support the integration of technology into the Physical Education learning process. One of the reasons is the funding that must be issued by the school. Not all schools have sufficient costs for purchasing, maintaining and upgrading all the requirements for the implementation of technology-based Physical Education learning so that the use of technology in Physical Education learning can be felt by teachers and students [13].

The challenge of the teacher becomes the second largest after the challenges that come from the environment. The teacher is the main actor for integrating technology into the teaching and learning process of Physical Education; therefore, teachers must be able to be technology literate. Technology integration for Physical Education teachers makes it easy to assess the results of student movements using digital cameras, and other programs to measure students' motor skills [5]. Most teachers have limitations in using computers and supporting programs that able to integrate technology into Physical Education, especially older teachers [7]. Some Physical Education teachers understand the use of technology in their daily lives, such as operating a smartphone, using a computer/ laptop, but they cannot implement it in the learning process of Physical Education [14]. The lack of Physical Education teachers' ability and the availability of training to grade their skills in operating technology outcomes is also a challenge in implementing technology-based Physical Education learning. This will cause a lack of Physical Education learning experience for Physical Education teachers to be able to integrate technology into the Physical Education learning process [7], [15].

Furthermore, the challenges that come from students must also be overcome immediately. Many students do not understand how to maximize the use of technology in the Physical Education learning process [3]. For example, most indicators using technology in learning Physical Education. 
2018.

students only understand the use of their smartphones for social media purposes, and not many students maximize the use of applications available on their smartphones for their physical health and fitness needs. Interest in the use of technology in learning also varies from student's gender. Most male students have lower interest rates compared to female students in participating in learning using technology [9].

Support from school residents to use technology in Physical Education learning is one of the challenges that must be faced. There are pro and contra of integrating technology into the learning process of Physical Education in schools will influence the policies of school leaders [8]. One of the policies is about the funding that will be provided by schools to support the integration of technology in Physical Education learning and the reform of the Physical Education curriculum that integrates technology into it [7].

The four challenges for using technology in Physical Education learning have been identified through this research, it is not impossible that there are many other challenges that have not yet been identified. This challenge will be different from the place and also the perspective of the Physical Education teachers in integrating technology in Physical Education learning [7].

\section{CONCLUSIONS}

The challenges that have been identified in this study include challenges that come from the environment (availability of facilities \& infrastructure supporting technology integration), teachers, students, and other school community support are some of the challenges that must be faced by all person that concerned to be able to integrate technology into learning. The challenge of using technology in Physical Education learning can be a platform for formulating solutions that can be used in overcoming problems of using technology in the Physical Education teaching and learning process.

\section{REFERENCES}

[1] J. Wyant and J. Baek, "Re-thinking technology adoption in Physical Education," Curric. Stud. Heal. Phys. Educ., vol. 0, no. 0, pp. 1-15,
[2] P. Legrain, N. Gillet, and C. Gernigon, "Integration of Information and Communication Technology and Pupils ' Motivation in a Physical Education Setting Self-Determination Theory," J. Teach. Phys. Educ., vol. 34 , no. 3, pp. 384-401, 2015.

[3] A. Casey and B. Jones, "Using digital technology to enhance student engagement in Physical Education," Asia-Pacific J. Heal. Sport Phys. Educ. 2, vol. 2, no. 2, pp. 37-41, 2011.

[4] B. Melton, "Evaluating a Physical Activity App in the Classroom: A Mixed Methodological Approach Among University Students," no. January, 2015.

[5] J. O. Loughlin, D. N1, and D. O. Grady, "Digital video: The impact on children 's learning experiences in primary Physical Education," Digit. video impact Child. Learn. Exp. Prim. Phys. Educ., vol. 19, no. 2, pp. 165-182, 2013.

[6] Y. Ju and H. Wan, "Analysis of Physical Education Teaching Mode Based on Computer Multimedia and Network System," Int. J. Database Theory Appl., vol. 9, no. 10, pp. 397-408, 2016.

[7] A. Villalba and M. D. González-rivera, "Obstacles Perceived by Physical Education Teachers to Integrating ICT," Turkish Online J. Educ. Technol., vol. 16, no. 1, pp. 83-92, 2017.

[8] D. J. Ayalogu, "ICT And The Teaching And Learning Of Physical And Health Education In Secondary Schools In Nigeria," Bassey Andah J., vol. 5, no. 3, pp. 120-129, 2012.

[9] H. Bisgin, "Analyzing the Attitudes of Physical Education and Sport Teachers towards Technology Analyzing the Attitudes of Physical Education and Sport Teachers towards Technology," Anthropol. ISSN, vol. 0073, no. 18, pp. 761-764, 2017.

[10] P. Tearle and G. Golder, "European Journal of Teacher Education The use of ICT in the teaching and learning of Physical Education in compulsory education: how do we prepare the workforce of the future?," Eur. J. Teach. Educ., vol. 31, no. October 2013, pp. 37-41, 2008.

[11] Y. Arslan, "Determination of Technopedagogical Content Knowledge Competencies of Preservice Physical Education Teachers: A Turkish Sample," J. Teach. Phys. Educ., vol. 34, no. 2, pp. 225-241, 2015.

[12] Sujoko, "Pemanfaatan Teknologi Informasi dan Komunikasi sebagai Media Pembelajaran di SMP Negeri 1 Geger Madiun," J. Kebijak. dan Pengemb. Pendidik., vol. 1, no. 1, pp. 71-76, 2013.

[13] Adesina, "ICT : Its Relevance in the Teaching and Learning of Physical Education in Nigeria," J. Emerg. Trends Educ. Res. Policy Stud., vol. 6, no. 3, pp. 236-239, 2015.

[14] S. Yildirim, R. Yuksel, S. Doganay, M. Gul, F. Bingol, and S. Dane, "Hearing in Visually Impaired Adolescents," Eur. J. Basic Med. Sci., vol. 3, no. 1, pp. 3-71, 2013.

[15] R. Kretschmann, "Physical Education Teachers' Subjective Theories About Integrating Information and Communication Technology (ICT) Into Physical Education," Turkish Online J. Educ. Technol., vol. 14, no. 1, pp. 68-96, 2015. 